\title{
Formiminotransferase Activity in Liver of Vitamin B12 Deficiency
}

\author{
By \\ Kazuo Ohara, Ryo Chiba, Yoshiro Ito and \\ Yoshihiko Takahashi \\ From the Department of Pediatrics, Faculty of Medicine, Tohoku \\ University, Sendai; Director: Prof. Ts. A r a k a wa \\ (Received for publication, March 25, 1964)

\begin{abstract}
Formiminotransferase activity in the liver was only slightly decreased when rats were made severely vitamin $B_{12}$ deficient by feeding with vitamin $B_{12}$-free diet for 30 days or more consecutive to the operation of forming a self-filling diverticulum of the small intestine.
\end{abstract}

In a preceding paper") from our Laboratory, an infant with an abnormally high level of "serum folic acid activity" was reported, and it was confirmed that this abnormality in folic acid metabolism was due to a congenital defect in formiminotransferase of the liver.

In our recent investigation'), it was found that in malnourished children, who showed ariboflavinotic signs and relatively low levels of serum vitamin $\mathbf{B}_{12}$, abnormally high levels of folic acid activity in serum developed after oral dose of folic acid. At present time this abnormal finding remains unsolved for us.

In 1962 Knowles and Prankard ${ }^{3)}$ suggested that there was a disturbance in folic acid metabolism - a possible decrease in formiminotransferase - in patients with pernicious anemia or with megaloblastic anemia due to vitamin $\mathrm{B}_{12}$ deficiency.

In these respects we have made present investigation in order to study the interrelationship between vitamin $B_{12}$ deficiency and formiminotransferase activity of the liver of rats.

\section{METHODS AND MATERIALS}

Each of the Wister rats, weighing from 30 to $50 \mathrm{~g}$, was maintained in an individual cage. Diet was given ad libitum. Standard diet was of the composition as shown in Table I. Vitamin $B_{12}$-free diet was of the same composition

大原和夫，千葉 良，伊藤義郎，高橋善彦 
TABLE I. Composition of Standard Diet for Rats

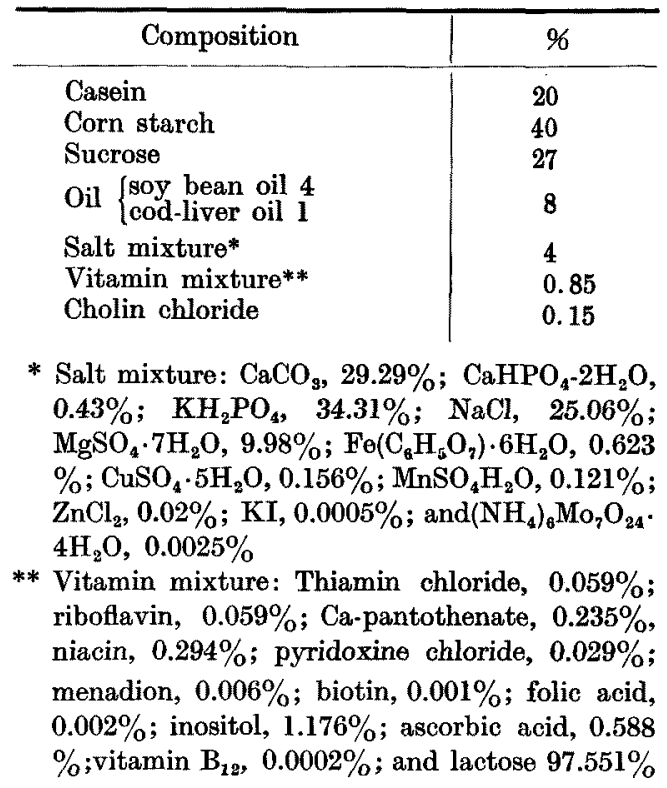

as that of the standard diet except for omission of vitamin $B_{12}$ from the vitamin mixture. The diet used in this experimentation was available from the Tanabe Hissu-amino-san Kenkyu Kikin, Osaka, Japan.

Operation of "self-filling diverticulum" of the small intestine: Diverticulum of the small intestine was formed according to the method described by Strauss et al.4) The small intestine was transected $40 \mathrm{~cm}$ from the ileocecal valve. The cut end of the distal intestine was anastomosed to the proximal intestine $8 \mathrm{~cm}$ from the cut end of the cephalad segment. The end of the proximal segment was tied off with a purse-string suture. Thus the normal direction of peristalsis in the intestinal segment of which a diverticulum was made, was towards the tied off end.

Rats were divided into 3 groups (Groups I, II and III). Group I consisted of 4 rats (Nos. 1, 7, 23 and 29) which were given vitamin $B_{12}$-free diet immediately following the operation for the self-filling diverticulum.

Group II included 6 rats (Nos. 8, 11, 14, 27, 28 and 40) which were given vitamin $B_{12}$-free diet without the operation.

Group III consisted of 6 rats (Nos. 9, 15, 21, 22, 25 and 30) which were given the standard diet without the operation.

Estimation of vitamin $B_{12}$ contents in serum and liver was performed according to the method ${ }^{5}$ ) adopted by Vitamin B Committee of Japanese Society of Vitaminology using L. leichimannii ATCC 4797. 
Formiminotransferase activity of the liver was measured in the same way as described in our preceding paper ${ }^{1)}$, using Tabor and Wyngarden's enzymatic method $^{6}$, and the activity was expressed as a difference of optical density between $420 \mathrm{~m} \mu$ and $355 \mathrm{~m} \mu$ read at one minute and/or 3 minutes after onset of the enzymatic reaction.

\section{RESULTS AND DISCUSSION}

\section{Experiment I}

Rats (Nos. 1 and 29) of Group I, which were given vitamin $B_{12}$-free diet for 30 days immediately following the operation for "self-filling diverticulum" of the small intestine. A rat (No. 14) of Group II was given vitamin $B_{12}$-free diet for 30 days, and a rat (No. 25) of Group III was control and given the standard diet.

As will be seen from Table II, serum vitamin $B_{12}$ contents of rats belonged to

TABLE II. Experiment I

\begin{tabular}{|c|c|c|c|c|c|}
\hline \multirow{2}{*}{ Group } & \multirow{2}{*}{$\begin{array}{l}\text { Nos. of } \\
\text { rats }\end{array}$} & \multirow{2}{*}{$\begin{array}{l}\text { Serum } \\
\text { vitamin } B_{12} \\
(\mathbf{m} \gamma / \mathbf{m l})\end{array}$} & \multirow{2}{*}{$\begin{array}{c}\text { Vitamin } \mathbf{B}_{12} \\
\text { content in } \\
\text { the liver } \\
(\mathrm{m} \gamma / \mathrm{g})\end{array}$} & \multicolumn{2}{|c|}{$\begin{array}{l}\text { Formiminotransferase } \\
\text { activity of the liver }\end{array}$} \\
\hline & & & & $\begin{array}{l}\text { Read at } \\
\text { one minute }\end{array}$ & $\begin{array}{l}\text { Read at } \\
3 \text { minutes }\end{array}$ \\
\hline $\begin{array}{c}\mathrm{I} \\
\text { (Self-filling } \\
\text { diverticulum } \\
\stackrel{+}{\mathrm{B}_{12} \text {-free diet) }}\end{array}$ & $\begin{array}{r}29 \\
1\end{array}$ & $\begin{array}{l}0.57 \\
0.48\end{array}$ & $\begin{array}{r}35 \\
107\end{array}$ & $\begin{array}{l}0.020 \\
0.024\end{array}$ & $\begin{array}{l}0.084 \\
0.049\end{array}$ \\
\hline$\underset{\left(\mathrm{B}_{12} \text {-free diet }\right)}{\mathrm{II}}$ & 14 & 0.58 & 116 & 0.045 & 0.094 \\
\hline $\begin{array}{c}\text { III } \\
\text { (Control) }\end{array}$ & 25 & 1.63 & 186 & 0.058 & 0.095 \\
\hline
\end{tabular}

* Liver homogenates used were prepared so as to be of protein levels of $11 \mathrm{mg} / \mathrm{ml}$. Formiminoglutamic acid in the reaction mixture was 0.2 micromole per tube.

Groups I and II were markedly reduced and amounted to about one-third of that of the control group, while vitamin $\mathrm{B}_{12}$ contents in the livers were reduced in a less degree than those of serum, even though a considerable decrease in vitamin $B_{12}$ concentration was found in the livers of rats of Group I. It is worthy of notice that a decrease in formiminotransferase activity of the liver, when measured at one minute, was almost proportional to the decrease in vitamin $B_{12}$ concentration of the liver. But such a relationship between vitamin $B_{12}$ content in the liver and formiminotransferase activity as above mentioned, was no more found when formiminotransferase activity was measured at 3 minutes' reading.

Thus it might be assumed that a slight inhibition of an early stage of the formiminotransferase reaction was brought about by a decrease in vitamin $B_{12}$ content in the liver of rats, so far as the condition described in Experiment I was 
concerned.

\section{Experiment II}

In this experiment, formiminoglutamic acid used in the reaction mixture was increased up to 1 micromole per tube, and influence of vitamin $B_{12}$ upon formiminotransferase activity was examined in vitro (cf. Table II).

Vitamin $B_{12}$ content in the liver of a rat of Group I (No. 23) was markedly reduced, but that of Group II (No. 11) showed no significant reduction from that of control (No. 15).

TABLE III. Experiment II

\begin{tabular}{|c|c|c|c|c|c|}
\hline \multirow{3}{*}{ Group } & \multirow{3}{*}{$\begin{array}{l}\text { Nos. of } \\
\text { rats }\end{array}$} & \multirow{3}{*}{$\begin{array}{c}\text { Vitamin } \mathrm{B}_{12} \\
\text { content } \\
\text { in the liver } \\
(\mathrm{m} \gamma / \mathrm{g})\end{array}$} & \multicolumn{3}{|c|}{$\begin{array}{l}\text { Formiminotransferase activity of the } \\
\text { liver (read at one minute) }\end{array}$} \\
\hline & & & \multirow{2}{*}{$\begin{array}{c}\text { Without } \\
\text { addition of } \\
\text { vitamin } B_{12}\end{array}$} & \multicolumn{2}{|c|}{$\begin{array}{l}\text { With addition of } \\
\text { vitamin } B_{12}\end{array}$} \\
\hline & & & & $15 \mathrm{~m} \gamma /$ tube & $150 \mathrm{~m} \gamma /$ tube \\
\hline $\begin{array}{c}\mathrm{I}^{*} \\
\text { (Diverticulum } \\
\mathrm{B}_{\mathbf{1 2}} \text {-free diet) }\end{array}$ & $\begin{array}{r}7 \\
23\end{array}$ & 45 & $\begin{array}{l}0.096 \\
0.130\end{array}$ & 0.119 & 0.118 \\
\hline $\begin{array}{c}\text { II } \\
\left(\mathrm{B}_{12}-\text { free diet }\right)\end{array}$ & $\begin{array}{r}8 \\
11\end{array}$ & 128 & $\begin{array}{l}0.180 \\
0.266\end{array}$ & & \\
\hline $\begin{array}{c}\text { III } \\
\text { (Control) }\end{array}$ & $\begin{array}{l}15 \\
30\end{array}$ & 150 & $\begin{array}{l}0.140 \\
0.160\end{array}$ & 0.124 & $\begin{array}{l}0.112 \\
0.156\end{array}$ \\
\hline
\end{tabular}

* Duration of feeding with vitamin $\mathbf{B}_{12}$-free diet with or without self-filling diverticulum varied from 30 to 40 days.

** Liver homogenates were prepared so as to be of protein level of $9.5 \mathrm{mg} / \mathrm{ml}$. Formiminoglutamic acid in the reaction mixture was 1 micromole per tube.

Respecting the formiminotransferase activity of the liver read at one minute of the enzymatic reaction, a considerable decrease was found in only one case (No. 7) out of 2 cases (Nos. 7 and 23) of Group I. This finding differed from that obtained in Experiment I and this might be due to a higher concentration of formiminoglutamic acid used in the reaction mixture.

No enhancement in formiminotransferase activity was brought about by addition of vitamin $B_{12}$ into the reaction systems prepared from the livers of vitamin $B_{12}$ deficient or normal rats.

Experiment III

In this experiment formiminotransferase activity of the liver was investigated in rats which were given vitamin $\mathrm{B}_{12}$-free diet as long as 70 days. As will be seen from Table IV, no significant decrease in the enzymatic activity was brought about in the liver of these rats in which serum vitamin $B_{12}$ was markedly reduced, but vitamin $\mathrm{B}_{12}$ content in the liver did not significantly differ from that of 
TABLE IV. Experiment III

\begin{tabular}{c|c|c|c|c|c}
\hline Group & $\begin{array}{c}\text { Nos. of } \\
\text { rats }\end{array}$ & $\begin{array}{c}\text { Serum } \\
\text { vitamin } B_{12} \\
(\mathrm{~m} \gamma / \mathrm{ml})\end{array}$ & $\begin{array}{c}\text { Vitamin } \mathrm{B}_{12} \\
\text { content } \\
\text { in the liver } \\
(\mathrm{m} \gamma / \mathrm{g})\end{array}$ & $\begin{array}{c}\text { Formiminotransferase } \\
\text { activity of the liver* }\end{array}$ \\
\hline II & 27 & 0.35 & 179 & 0.158 & 0.405 \\
(Bead at one & $\begin{array}{c}\text { Read at } \\
\text { minute }\end{array}$ & 3 minutes \\
\hline III & 28 & 0.52 & 132 & 0.205 & 0.514 \\
(Control) & 40 & 0.48 & 135 & 0.144 & 0.390 \\
& 21 & 1.33 & 224 & 0.148 & 0.400 \\
& 22 & 1.41 & 184 & 0.160 & 0.425 \\
& 21.14 & 253 & 0.177 & 0.459
\end{tabular}

* Liver homogenates were so prepared as to be of protein level of $10 \mathrm{mg} / \mathrm{ml}$. Formiminoglutamic acid in the reaction mixture was 1 micromole per tube.

the control.

\section{CONCLUSION}

In summarizing the results obtained from Experiments I-III, the following points should be noticed:

1) Vitamin $B_{12}$ content in serum was markedly reduced in rats which were given vitamin $\mathrm{B}_{12}$-free diet for 30 days or more.

2) Vitamin $B_{12}$ content in the liver was not so markedly reduced as that of serum even when rats were given vitamin $B_{12}$-free diet as long as 70 days.

3) A marked decrease in vitamin $B_{12}$ content of the liver was brought about in rats which were given vitamin $B_{12}$-free diet for more than 30 days consecutive to the operation for self-filling diverticulum of the small intestine.

4) Formiminotransferase activity of the liver did not decrease in rats, when vitamin $B_{12}$ was markedly decreased in serum but not in the liver.

5) Formiminotransferase activity of the liver was only slightly decreased in certain cases of rats when vitamin $B_{12}$ was markedly decreased in the liver.

6) An addition of vitamin $B_{12}$ to the assay media did not bring about any enhancement of formiminotransferase activity of the livers from normal or vitamin $B_{12}$ deficient rats.

Basing upon the results above mentioned we were not in favor of the opinion that vitamin $B_{12}$ deficiency interfered definitely with the activity of formiminotransferase in the liver of rats.

\section{Acknowledgment}

The authors are grateful to Dr. I. Ohara, Surgical Clinic, Tohoku University, for the operation for self-filling diverticulum of the small intestine of rats. This work was supported partly by a grant in Aid for Developmental Scientific Research of Ministry of Education. 


\section{References}

1) Arakawa, Ts. „Ohara, K., Kudo, Z., Tada, K., Hayashi, T. \& Mizuno, T., Tohoku J. exp. Med., 1963, 80, 370 .

2) Ito, Y., Chiba, R. \& Sato, M., unpublished.

3) Knowles, J.O. \& Prankard, T.A.J., Clin. Sci., 1962, 22, 237.

4) Strauss, E.W., Donaldson, R.M.Jr. \& Gardner, F.H., Lancet, 1961, 11, 736.

5) Vitamin B Committee of Japanese Society of Vitaminology, Vitamins (Jap.), 1960, 19, 438.

6) Tabor, H. \& Wyngarden, L., J. biol. Chem., 1959, 234. 1830. 